\title{
Flood Inundation Mapping along the Lower Reach of Kelani River Basin under the Impact of Climatic Change
}

\author{
M. M. G. T. De Silva, S. B. Weerakoon, Srikantha Herath, U. R. Ratnayake and \\ Sarith Mahanama
}

\begin{abstract}
The downstream low lying region of the Kelani River including the Colombo suburbs, experience severe inundation due to heavy rainfalls in the upper basin of the Kelani River. Occurrence of heavy rainfalls is expected to be more frequent in the tropics with the impact of climatic change (IPCC, 2007). Therefore, understanding future rainfall intensity in the river basin and inundation in the low lying region along the lower reach of the Kelani River is extremely important as this is a region with a high population density and economic activities in the suburbs of the capital.
\end{abstract}

The present study analyses the potential extreme rainfalls and resulting flood inundation along the lower Kelani River. Coarse grid atmospheric parameters provided by Global Climate Model (GCM) models for A2 (high emission scenario) and B2 (low emission scenario) scenarios of Intergovernmental Panel on Climate Change (IPCC, 2007) were downscaled to local scale by applying Statistical Downscaling Model (SDSM). Flood discharge and inundation along the Kelani River reach below Hanwella were analyzed by applying two-dimensional flood simulation model (FLO-2D). Inflow to the model at Hanwella, is estimated by the Hydrologic Engineering Center - Hydrologic Modeling System (HEC-HMS) model under future extreme rainfall events. Areas vulnerable to inundation under the above climatic change scenarios are presented.

Keywords: Extreme rainfall, Flood inundation, Climatic change

\section{Introduction}

Climate change is defined as statistically significant variation in either mean state of the climate or in its variability, persisting for an extended period (typically decades or longer). It may be due to natural internal processes or external forcing or to persistent anthropogenic changes in the composition of the atmosphere or in land use [15]. Climate change directly affects precipitation and temperature. High intense rainfalls, frequent and prolonged droughts are some examples. It has been predicted that the implications of climatic change on Sri Lanka are variations in rainfall patterns, sea level rise, and temperature [3].

Two monsoon systems, the Southwest (MaySep) and the Northeast (Nov-Feb) and development of extreme low pressure conditions in the Bay of Bengal also have direct impacts on the rainfall patterns in Sri Lanka. Anomalously high seasonal precipitation typically associated with La Nina phenomenon and cyclonic storms which originate from the Bay of Bengal are usually the main reasons for devastating floods in the island.
This study discussed the frequencies of high intensity precipitation with their inundation extents in the Kelani River basin, produced under IPCC Special Report on Emissions Scenarios (SRES) A2 and B2 scenarios [16]. Both $\mathrm{A} 2$ and $\mathrm{B} 2$ emphasize on rapidly growing selfreliant nations while B2 accounts for more ecologically friendly growth. If extreme precipitation events are becoming more frequent in the $21^{\text {st }}$ century as manifested by

Eng. (Ms) M. M. G. T. De Silva AMIE(Sri Lanka), BScEng (Peradeniya), MPhil candidate, Dept. of Civil Engineering., Uni. of Peradeniya.

Eng. (Prof.) S. B. Weerakoon, FIE(Sri Lanka), Int. PE SL, C. Eng, BScEng (Peradeniya), MEng, PhD (Uni. of Tokyo), Professor of Civil Engineering, Dept. of Civil Engineering, Uni. of Peradeniya

Prof. Srikantha Herath, BScEng (Peradeniya), MEng (AIT, Thailand), DEng (Uni. of Tokyo), Senior Academic Programme Officer, UNU-ISP, Tokyo, Japan

Eng. (Dr.) U. R. Ratnayake, AMIE(Sri Lanka), C. Eng, BScEng (Peradeniya), MEng, DEng (AIT, Thailand), Senior Lecturer, Dept. of Civil Engineering, Uni. of Peradeniya.

Dr. Sarith Mahanama, BScEng (Peradeniya), PhD (Uni. of Hong Kong), Research Scientist, NASA Goddard Space Flight Center, Greenbelt, Maryland, USA 
ever changing global climate system, the Kelani River basin is one of the most vulnerable river basins for floods and costly flood damages since the river flows through the commercial capital [12].

\section{Study Area}

The Kelani River basin is located in between Northern latitudes $6^{\circ} 47^{\prime}$ to $7^{\circ} 05^{\prime}$ and Eastern longitudes $79^{\circ} 52^{\prime}$ to $80^{\circ} 13^{\prime}$. The basin area is about $2230 \mathrm{~km}^{2}$ with two distinct types, as the upper basin is mountainous and the lower basin which is below Hanwella, has plain features.

The basin receives about $2400 \mathrm{~mm}$ of average annual rainfall and carries a peak flow of about $800-1500 \mathrm{~m}^{3} / \mathrm{s}$ during monsoon seasons, to the Indian Ocean. The flood level gauge at Nagalagam Street (Colombo) defines the severity of the flood as; minor floods (level between $5 \mathrm{ft} / 1.5 \mathrm{~m}$ and $7 \mathrm{ft} / 2.1 \mathrm{~m}$ ), major floods (level is between $7 \mathrm{ft} / 2.1 \mathrm{~m}$ and $9 \mathrm{ft} /$ $2.7 \mathrm{~m}$ ), and severe flood (level exceeds $9 \mathrm{ft} / 2.7$ m) [5].

With climatic change impacts, a proper understanding of occurrence of rainfall, flood forecasting and inundation mapping in Kelani River basin are very important due to the occurrence of frequent floods and the resulting social and economic loss. According to the Disaster Management Centre (DMC), more than 38,000 families living in flood plains of Kelani River were affected during the 2008 flood [18], while more than 78,000 families were affected during the 2010 flood [17]. Moreover, Irrigation Department records show that there were two consecutive severe floods which occurred during the year 2008.

\section{Methodology}

\subsection{Preparation of data}

Topographic data of the basin were obtained from Shuttle Radar Topographic Mission (SRTM) data as Digital Elevation Model (DEM). The SRTM-DEM data, with a horizontal resolution of approximately $90 \mathrm{~m}$ near the equator and a vertical resolution of $1 \mathrm{~m}$, constitutes the finest resolution and most accurate topographic data available for most of the globe [11]. According to a study carried out in the Ruhuna basin, the most useful data were the SRTM DEM at $90 \mathrm{~m}$ resolution. The slope map generated using the SRTM DEM was very useful to identify low lying areas [9]. SRTM DEM has also been used in the hydrological modeling of upper Kotmale basin in Sri Lanka [6].

Inflow hydrograph at Hanwella was generated by HEC-HMS and the rainfall of the lower basin was generated by Statistical DownScaling Model (SDSM). Land use data was from the Department of Survey, Sri Lanka at 1:50,000 scale.

\subsection{Rainfall Modeling}

Statistical Downscaling Model (SDSM) which is designed to downscale GCM data into regional level, was applied to downscale precipitation for the basin up to 2099 under A2 and B2 scenarios published by IPCC. The model was calibrated for the period from 1961 to 1975 and validated from 1976 to 1990. SDSM uses linear regression techniques between predictor (observed large scale climate fields) and predictand (local observed meteorological variables) to produce multiple realizations of synthetic daily weather sequences. The predictor variables provide daily information about large scale atmosphere condition, while the predictand describes the condition at the site level [2].

Accordingly in order to ensure that the downscaling method in reproducing the mean and variability of observed variable in the basin, an uncertainty analysis was carried out. Table 1 shows the statistical parameters of annual maximum daily rainfall for simulated and observed data during the periods of calibration (1961-1975) and validation (19761990).

Table 1 - Statistical parameters affect to uncertainty

\begin{tabular}{|c|c|c|c|c|}
\hline Parameter & $\begin{array}{c}1^{\text {st }} \\
\text { Quartile }\end{array}$ & Median & $\begin{array}{c}3^{\text {rd }} \\
\text { Quartile }\end{array}$ & Variance \\
\hline Obs 61-75 & 119 & 149 & 192 & 2101 \\
\hline A2 61-75 & 118 & 164 & 186 & 1723 \\
\hline B2 -61-75 & 111 & 153 & 183 & 1609 \\
\hline Obs 76-90 & 115 & 151 & 174 & 2136 \\
\hline A2 76-90 & 117 & 148 & 163 & 2089 \\
\hline B2 76-90 & 119 & 132 & 152 & 2199 \\
\hline
\end{tabular}

According to the statistical parameters, $1^{\text {st }} \& 3^{\text {rd }}$ quartiles, and median lie in the same range as observed while the variance shows some 
deviation from the observed values during the calibration period. All the statistical parameters from simulations show a satisfactory agreement with observed values during the validation period.

Figures 1(a) and 1(b) show the uncertainty of forecasted annual maximum daily rainfall with observed values for calibration and validation periods respectively, for lower basin. The simulation results for validation period under A2 and B2 scenarios show good correlation with observed data

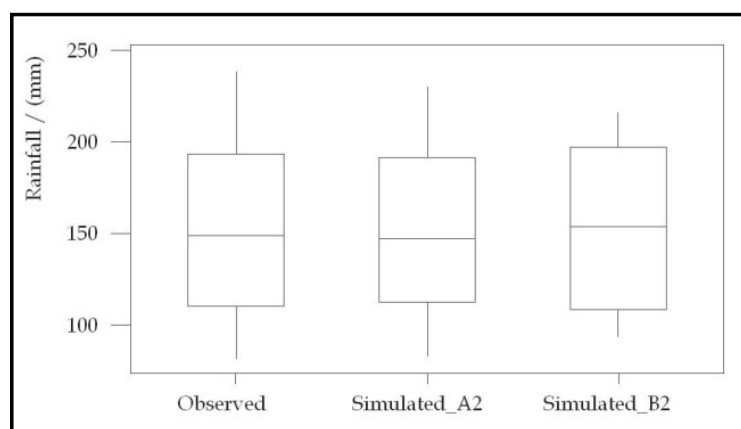

(a) Calibration period

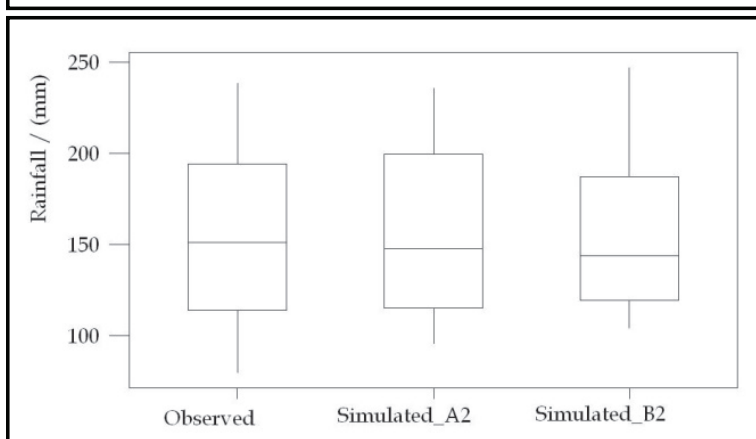

(b) Validation period

Figure 1 - Box plots to compare observed and downscaled results for annual maximum daily rainfall

Forecasted rainfall of the upper basin by SDSM was used in HEC-HMS model to generate the flow at Hanwella. HEC-HMS, developed by the US Army Corps of Engineers, is designed to simulate the precipitation-runoff processes of watershed systems. Numerous past studies have shown this model to provide accurate and useful results in flood related studies [8].

The upper basin is about $1740 \mathrm{~km}^{2}$ and the time of concentration from upper basin which is from the "Samanala" mountain to Hanwella is about 2 days and at the edge of the lower basin it is about 2.5 days. This could be due to substantial losses because of infiltration and depression storage, within the upper basin which has a vegetation cover of about $70 \%$. Frequency analysis of return period was carried out for 3 day total rainfall of the upper basin by using forecasted data from 2020 to 2099.

The lower basin has an area of about $500 \mathrm{~km}^{2}$ with plain features and ample amount of builtup areas. The time of concentration of lower basin at the edge of the basin is around 12 hours. Therefore, one day rainfall in the lower basin can cause severe floods. Therefore, the daily rainfall forecasted from 2020 to 2099 was used for the frequency analysis within the lower basin.

Accordingly the flood and inundation analysis in the lower basin was carried out using 3 day rainfall events of 50 year and 100 year return periods of upper basin and daily rainfall events of 50 year and 100 year return periods of lower basin. Table 2 and 3 illustrate the summary of results of frequency analysis for upper and lower basins respectively by applying the Gumbel distribution [4].

Table 2 - 3 day rainfall for upper basin

\begin{tabular}{|c|c|c|}
\hline \multirow{2}{*}{$\begin{array}{c}\text { Return Period } \\
\text { / (yr) }\end{array}$} & \multicolumn{2}{|c|}{ 3 day rainfall / (mm) } \\
\cline { 2 - 3 } & A 2 & B 2 \\
\hline 50 & 415 & 393 \\
\hline 100 & 456 & 432 \\
\hline
\end{tabular}

Table 3 - Daily rainfall for lower basin

\begin{tabular}{|c|c|c|}
\hline \multirow{2}{*}{$\begin{array}{c}\text { Return Period } \\
/ \text { (yr) }\end{array}$} & \multicolumn{2}{|c|}{ Daily rainfall / (mm) } \\
\cline { 2 - 3 } & A 2 & B 2 \\
\hline 50 & 244 & 227 \\
\hline 100 & 268 & 248 \\
\hline
\end{tabular}

\subsection{D flow modeling}

Two-dimensional flood simulation model, FLO2D was utilized to analyse and map inundation areas. FLO-2D is two-dimensional flood routing model that distributes a flood hydrograph over a system of square grid elements. FLO-2D numerically routes a flood hydrograph while predicting the area of inundation and simulating flood wave attenuation [13].

The FLO-2D system consists of processor programs to facilitate graphical editing and mapping that simulate channel and floodplain details. The Grid Developer System (GDS) generates a grid system that represents the topography as a series of small tiles. The FLO2D model has components for rainfall, channel 
flow, overland flow, infiltration, levees and other physical features [14].

FLO-2D moves the flood volume around on a series of tiles for overland flow or through stream segments for channel routing. Flood wave progression over the flow domain is controlled by topography and resistance to flow. Flood routing in two dimensions is accomplished through a numerical integration of the continuity equation and the equations of motion [14].

$$
\begin{gathered}
\frac{\partial h}{\partial t}+\frac{\partial(h V)}{\partial x}=i \\
S_{f}=S_{0}-\frac{\partial h}{\partial x}-\frac{V}{g} \times \frac{\partial V}{\partial x}-\frac{1}{g} \times \frac{\partial V}{\partial t}
\end{gathered}
$$

$h$ - Flow depth

$V$ - Depth-averaged velocity

$i$ - Excess rainfall intensity

$S_{f}$ - Friction slope

$S_{0}$ - Bed slope

The differential form of the continuity and momentum equations in the FLO-2D model is solved with a central, finite difference numerical scheme as one dimensional flow in the channel and two dimensional flow in the flood plain.

\subsection{Model calibration}

The GDS was used to generate $250 \mathrm{~m} \times 250 \mathrm{~m}$ grids covering the river basin. The topography of the basin area was determined by using the downloaded DEM from SRTM. Manning's coefficients over the basin were allocated according to the land use patterns. The model was calibrated for the extreme event which occurred in November 2005, by comparing the flow at Nagalagam Street gauging station. The validation was carried out for the discharge at Nagalagam Street by using the events which occurred in April 2008, May 2008 and May 2010. Figure 2 and 3 show the observed and simulated hydrographs for 2005 flood event and 2010 flood event respectively. The observed data during 2010 flood event, the rising and falling limbs show some oscillations and which could be due to external factors.

Normalized Objective Function (NOF), NashSutcliffe efficiency $\left(R_{N S}^{2}\right)$ and percentage bias $\left(\delta_{b}\right)$ given in equations (3) to (5) respectively, were used to evaluate the Goodness of Fit between the simulated and observed flows.

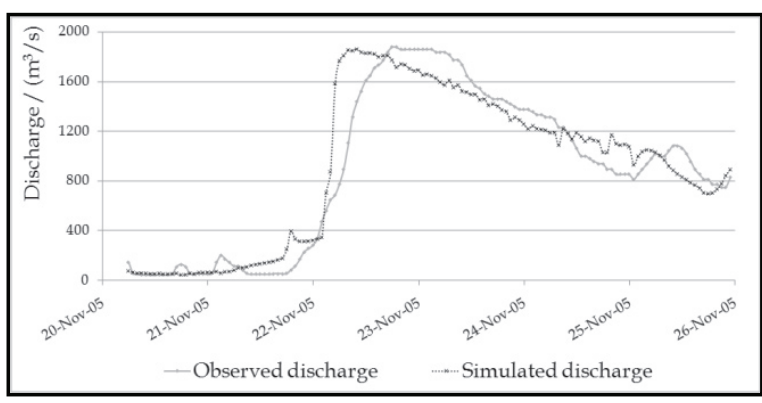

Figure 2 - Time series of observed and simulated flow at Nagalagam Street during 2005 flood

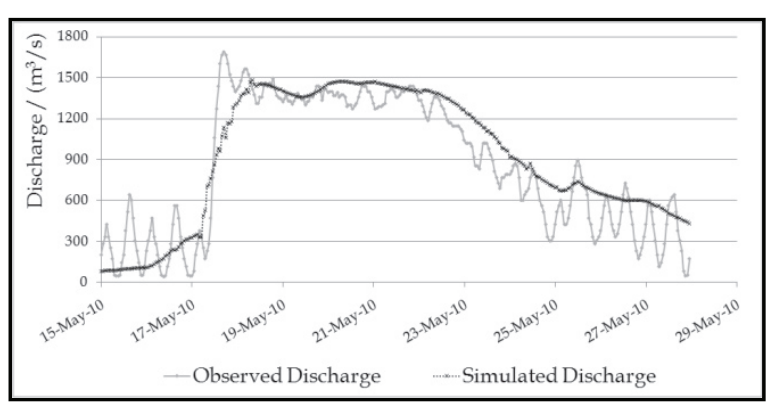

Figure 3 - Time series of observed and simulated flow at Nagalagam Street during 2010 flood

$N O F=\frac{1}{\bar{O}} \sqrt{\frac{1}{n} \sum_{i=1}^{n}\left(O_{i}-S_{i}\right)^{2}}$

$R_{N S}^{2}=1-\frac{\sum_{i=1}^{n}\left(S_{i}-O_{i}\right)^{2}}{\sum_{i=1}^{n}\left(O_{i}-\bar{O}\right)^{2}}$

$\delta_{b}=\left|\frac{\sum_{i=1}^{n}\left(S_{i}-O_{i}\right)}{\sum_{i=1}^{n} O_{i}}\right| \times 100 \%$

Where,

$O_{i}$ - Observed discharge

$S_{i}$ - Simulated discharge

$n$ - Number of data points

$\bar{O}$ - Mean of the observed discharge

Table 4 shows the Goodness of Fit of the simulation results for selected flood events.

Table 4 - Goodness of Fit

\begin{tabular}{|c|c|c|c|}
\hline Event & NOF & $R_{N S}^{2}$ & $\delta_{b} /(\%)$ \\
\hline Nov. 2005 & 0.27 & 0.84 & 21 \\
\hline April 2008 & 0.33 & 0.65 & 25 \\
\hline May 2008 & 0.26 & 0.59 & 18 \\
\hline May 2010 & 0.32 & 0.68 & 23 \\
\hline
\end{tabular}


The results indicate that the model is capable of simulating discharge at the Nagalagam Street gauging station.

The simulated inundation extents were compared with the observed extents for the flood events in May 2008 and May 2010 from ALOS/PALSAR HH data set and flood inundation maps published by the Disaster Management Center (DMC) respectively (the only events with inundation maps available). The observed inundation extents in the basin published by the DMC are shown in Figure 4(a) and shaded regions indicate the area subjected to inundation. The simulated result for the same event is shown in Figure 4(b) and Figure 4(c) illustrates the combination of the observed and simulated inundation extents.

The inundation extents were compared by considering the fraction of the domain classified correctly by the model, which was successfully utilized in some past studies ([1],[7] and [10]) and the equation used is as follows.

$F=\frac{S_{\text {obs }} \cap S_{\text {mod }}}{S_{\text {obs }} \cup S_{\text {mod }}} \times 100$

$S_{o b s}$ and $S_{m o d}$ are set of domain sub regions (cells or pixels) observed to be inundated and predicted as inundated respectively and $F$ is the Measure of Fit. If the simulated extents exactly overlap with the observed extents $F$ value is $100 \%$ and if no simulated extent overlaps with observed extents $F$ value is 0 . The $F$ value is $71 \%$ for May 2010 event and $69 \%$ for May 2008 event. These values are in acceptable range with compared to past studies.

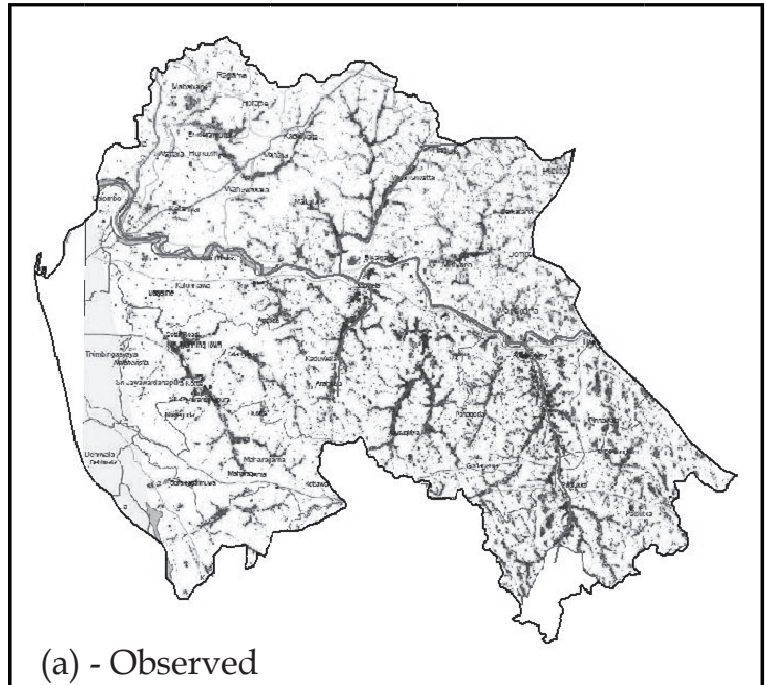

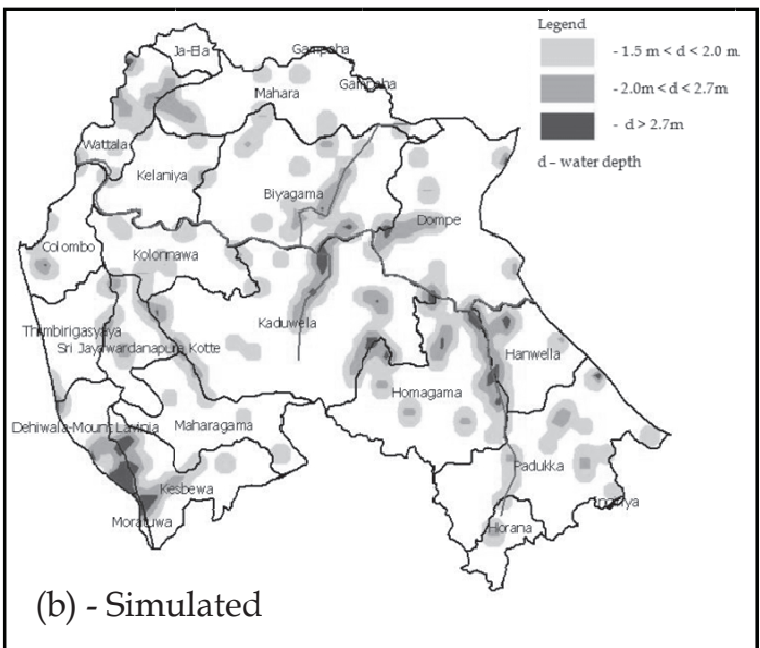

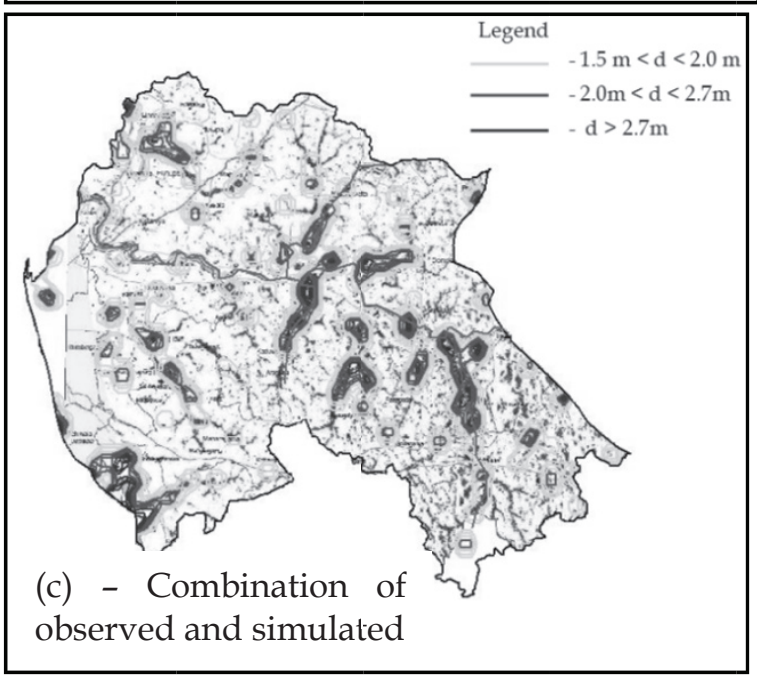

Figure 4 - Inundation extents due to flooding in May 2010

The Goodness of Fit parameters of the discharge at Nagalagam Street gauging station and the inundation extents of the simulations show good agreement with the observed. Accordingly, the calibrated model was used for future forecasts.

\section{Results and Discussions}

Flood inundation extents due to the rainfall of 50 year and 100 year return periods under A2 and B2 scenarios were computed by the FLO2D model. 


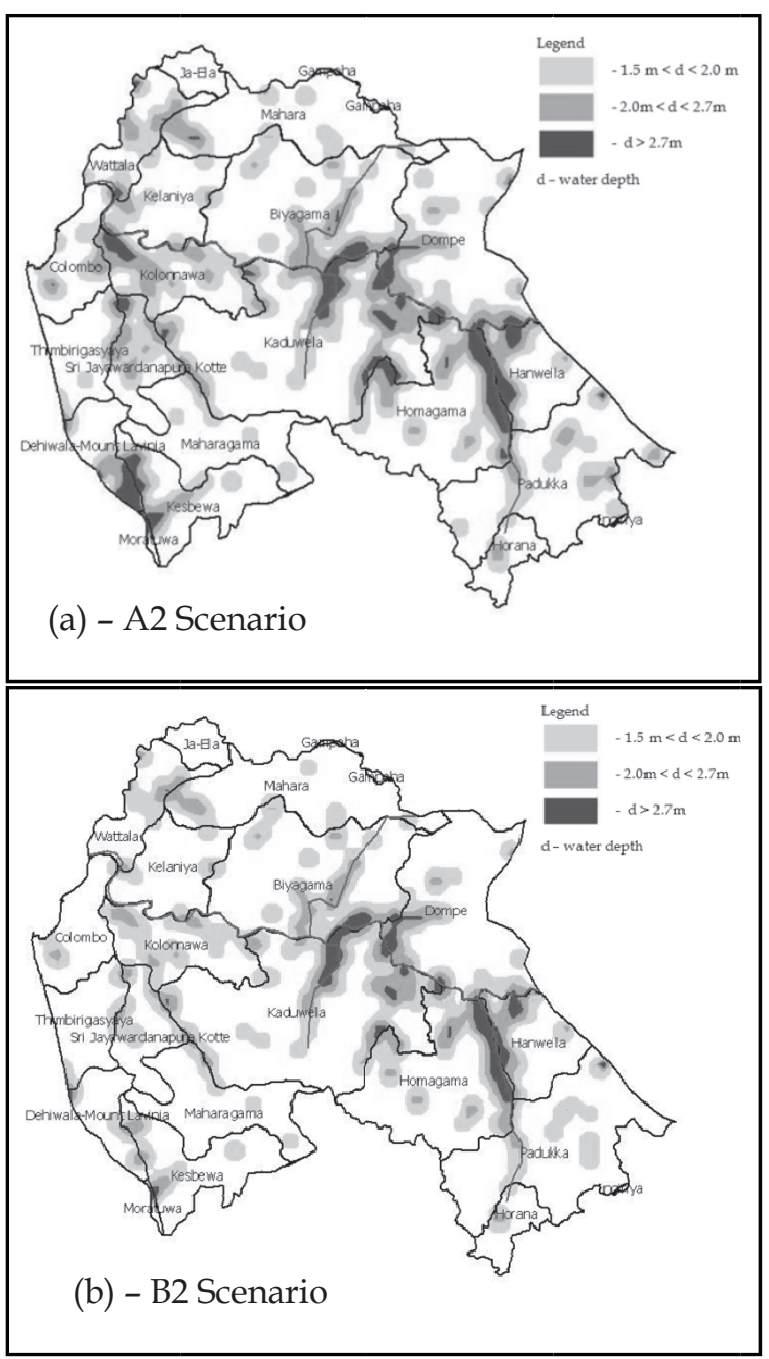

Figure 5 - Inundation extents due to 3 day rainfall of 50 year return period in the upper basin and daily rainfall of 50 year return period in the lower basin

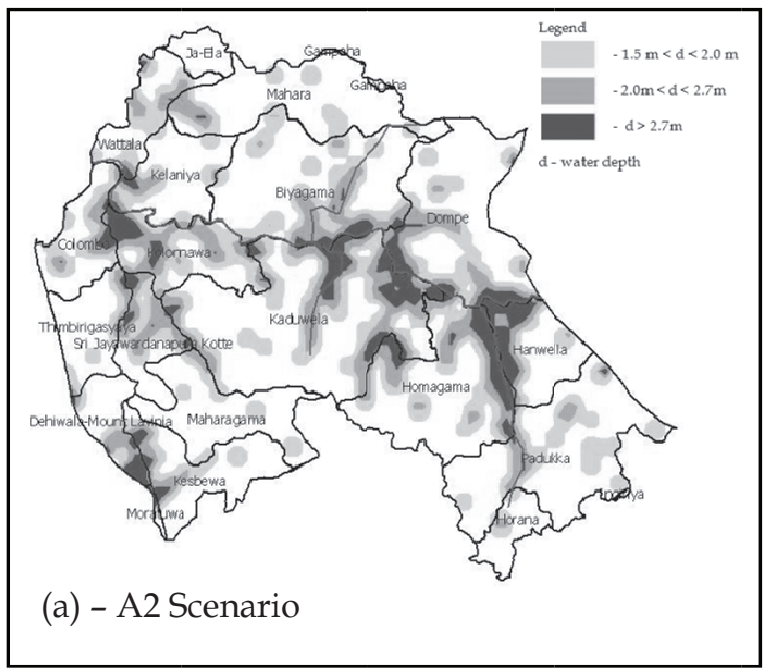

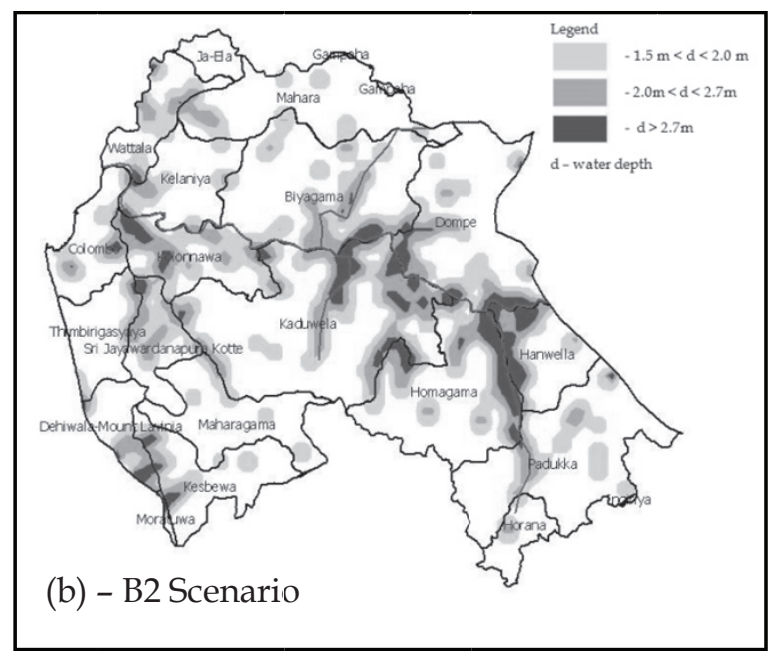

Figure 6 - Inundation extents due to 3 day rainfall of 100 year return period in the upper basin and daily rainfall of 100 year return period in the lower basin

Figure 5 shows that the flood corresponding to rainfalls of 50 year return period causes inundation in Colombo and Gampaha districts. Some areas in Hanwella, Kaduwela, Kolonnawa, Biyagama, Kelaniya and Colombo Divisional Secretariat (DS) divisions are identified as more vulnerable regions for flood inundation.

Figure 6 shows inundated areas corresponding to rainfall of 100 year return period. Compared to the 50 year results, the inundation extents expand to Kelaniya, Thimbirigasyaya and Sri Jayawardanapura Kotte DS divisions too. The inundation extents and depths corresponding to each flood event considered are given in Table 5.

Table 5 - Inundation extents for floods

\begin{tabular}{|c|c|c|c|c|}
\hline \multirow{2}{*}{$\begin{array}{c}\text { Inundation } \\
\text { depths }\end{array}$} & \multicolumn{4}{|c|}{ Inundation extents $/\left(\mathrm{km}^{2}\right)$} \\
\cline { 2 - 5 } & $\begin{array}{c}50 \\
\text { year } \\
\text { return } \\
\text { period } \\
\text { A2 }\end{array}$ & $\begin{array}{c}50 \\
\text { year } \\
\text { return } \\
\text { period } \\
\text { B2 }\end{array}$ & $\begin{array}{c}100 \\
\text { year } \\
\text { return } \\
\text { period } \\
\text { A2 }\end{array}$ & $\begin{array}{c}100 \\
\text { year } \\
\text { return } \\
\text { period } \\
\text { B2 }\end{array}$ \\
\hline $1.5-2.0 \mathrm{~m}$ & 390.7 & 384.3 & 396.3 & 391.1 \\
\hline $2.0-2.7 \mathrm{~m}$ & 163.1 & 77.7 & 207.7 & 194.7 \\
\hline$>2.7 \mathrm{~m}$ & 28.7 & 15.6 & 49.4 & 33.0 \\
\hline
\end{tabular}

The research outcomes are useful for identifying the hazardous areas due to floods. Depending on the frequency and severity of the floods, the areas could be developed and protected in order to minimize the risk of damage to lives and properties. In addition, flood warning systems and evacuation centres could be established in order to prevent losses. 
Further, inundation maps could be published in public places along with awareness programs which would guide people to find safe places during severe floods.

\section{Conclusions}

2-D inundation model has been developed to lower Kelani basin to estimate inundation under extreme rainfall to the basin.

Rainfall under climatic change scenarios, A2 and B2 were downscaled from GCM shows that the 50 year return period daily rainfall was 244 $\mathrm{mm}$ and $227 \mathrm{~mm}$ under A2 and B2 scenarios respectively and 100 year return period daily rainfall was $268 \mathrm{~mm}$ and $248 \mathrm{~mm}$ under A2 and B2 scenarios respectively at lower basin. The 50 year return period 3 day rainfall was $415 \mathrm{~mm}$ and $393 \mathrm{~mm}$ under $\mathrm{A} 2$ and B2 scenarios respectively and 100 year return period 3 day rainfall was $456 \mathrm{~mm}$ and $432 \mathrm{~mm}$ under A2 and B2 scenarios at upper basin.

Some areas in Hanwella, Kaduwela, Kolonnawa, Biyagama, Kelaniya and Colombo DS divisions are identified as vulnerable areas for inundation under rainfalls of 50 year return period. The inundation extents under 100 year return period rainfall expands to Kelaniya, Thimbirigasyaya and Sri Jayawardanapura Kotte GN divisions too.

The findings are useful to plan implementation strategies to minimize flood damages in the lower Kelani river basin under expected climatic change impacts.

\section{Acknowledgements}

The authors would like to convey their sincere gratitude to UN-CECAR program of United Nations University, Tokyo, Japan, for the guidance and the Mitsui fund for their financial support for this research. The hydrological and meteorological data for the study were obtained from the Department of Irrigation and Department of Meteorology.

\section{References}

1. Aronica G., P. D. Bates and M. S. Horritt, "Assessing the Uncertainty in Distributed Model Predictions using Observed Binary Pattern Information within GLUE", Hydrological Processes Journal, Vol. 16, 2002.

2. Bekele H. M., Thesis, "Evaluation of Climate Change Impact on Upper Blue Nile Basin
Reservoirs", School of Post Graduate Studies, Arba Minch University, 2009.

3. Basnayake B.R.S.B., Rathnasiri J. and Withange J.C., "Rainfall \& Temperature Scenarios for Sri Lanka under the Anticipated Climate Change", AIACC project, AS 12 presentation, 2007.

4. Chow, V. T., Maidment, D. R., Mays, L. W., Applied Hydrology, International ed., Singapore, 1988.

5. Gunasekara, I. P. A., "Flood Hazard Mapping in Lower Reach of Kelani River", Journal of Engineer Vol. XXXXI, No. 05, 2008.

6. Hunukumbura J.M.P.B, Thesis, Setting up of an Experimental Basin and Development of a CellBased Model to Derive Direct Runoff Hydrographs for Ungauged Basins, Department of Civil Engineering, University of Peradeniya, 2006.

7. Horritt M.S., “A Methodology for the Validation of Uncertain Flood Inundation Models", Journal of Hydrology, Vol. 326, 2006.

8. Knebla, M. R., Yanga, Z.-L., Hutchisonb, K. \& Maidmentc, D.R., "Regional Scale Flood Modeling using NEXRAD Rainfall, GIS, and HEC-HMS/RAS: a case study for the San Antonio River Basin Summer 2002 storm event", Journal of Environmental Management 75 (2005) 325-336, 2004.

9. Md. A. Islam, p. S. Thenkabail, R. W. Kulawardhana, R. Alankara, S. Gunasinghe, C. Edussriya and A. Gunawardana, "Semi-Automated Methods for Mapping Wetlands using Landsat ETM+ and SRTM Data", International Journal of Remote Sensing, Vol. 29, No. 24, 2008.

10. Nandalal H.K, Thesis, "Flood Risk Management Incorporating Stakeholder Participation and Climate Variability", University of Peradeniya, 2011.

11. Rennó, C. D., Nobre, A. D., Cuartas, L. A., Soares, J. V., Hodnett, M. G., Tomasella, J., Waterloo, M. J., "HAND, a New Terrain Descriptor using SRTM-DEM: Mapping Terra-Firme Rainforest Environments in Amazonia", Remote Sensing of Environment, RSE-07152.

12. Silva A., "Climate Change and Sri Lanka”, 2009.

13. Tetra Tech, Inc., Surface Water Group, "Development of the Middle Rio Grande FLO-2D Flood Routing Model Cochiti Dam to Elephant Butte Reservoir", 2004.

14. FLO-2D Reference manual, 2009.

15. IPCC (2001). Climate Change, 2001 Scientific Basis Pg 18 http://chaser.env.nagoyau.ac.jp/ kengo/lec/IPCC_TAR-FRONT.pdf

16. IPCC (2007), Climate Change.

17. Disaster Management Centre (DMC), Flood Situation Report, Colombo, Sri Lanka, 2010.

18. National Disaster Relief Services Centre (NDRSC), Floods \& Landslides Situation Report May/June 2008, 2008. 
